\title{
Avaliação da Qualidade Microbiológica de Salames Comercializados no Município de Chapecó (Sc)
}

\author{
Alice Marocco (I), Raquel Zeni Ternus (II,I) \\ (I) Unochapecó - Universidade Comunitária da Região de Chapecó (Rua Sen. Attílio Fontana, \\ 591E. Bairro Efapi, Chapecó, SC), (II) UFRGS - Universidade Federal do Rio Grande do Sul \\ (Av. Paulo Gama, 110, Bairro Farroupilha, Porto Alegre, RS)
}

\section{Resumo}

Os salames são largamente produzidos por grandes agroindústrias e por médios e pequenos agricultores familiares na região oeste de Santa Catarina. Estão inseridos dentro da cultura regional e são muito consumidos como petiscos e como ingredientes de pratos mais elaborados. Pelo fato de o salame ser um produto embutido consumido cru, há a preocupação com o desenvolvimento de bactérias causadoras de doença de origem alimentar. A manipulação inadequada e falta de controle das condições ideais do processo de fabricação são situações associadas a má qualidade do produto final. Portanto, o objetivo deste trabalho foi avaliar as características microbiológicas de cinco marcas de salame (coloniais/artesanais e industriais), produzidos em estabelecimentos possuidores de Sistema de Inspeção Municipal, Estadual e Federal, comercializados em feiras livres e supermercados, e avaliar a estabilidade das condições durante um período de estocagem. Foram analisadas a presença de Salmonella spp., e contagem de Staphylococcus coagulase positiva, Clostridium sulfito redutores e C. perfringens, e de coliformes totais e termotolerantes, seguindo-se a metodologia preconizada pelo FDA (APHA). Adicionalmente, foram realizadas medições para teor de umidade, de nitrito e cloreto de sódio. As amostras de salames foram analisadas com 10 e 30 dias de fabricação. Os resultados mostram a influência do tempo de estocagem sobre as características físico-químicas. Foi possível observar também que $75 \%$ das amostras apresentaram valores de Staphylococcus coagulase positiva acima do valor aceitável pela legislação no tempo de 30 
dias de estocagem. No prazo de 10 dias de fabricação, $100 \%$ das amostras apresentaram resultados fora do padrão, sendo que as amostras coloniais/artesanais apresentaram maiores contagens de UFC/g do que as amostras industriais, indicando condições precárias de higiene e manipulação na produção de salames das amostras analisadas. Também constatou-se que $86,6 \%$ das amostras analisadas estavam em desacordo com a legislação brasileira vigente (RDC 12/2001), pois apresentaram um ou mais parâmetros, com valores acima dos limites estabelecidos.

Palavras-Chave: Coliformes, Salmonella spp., vida útil Agência de Fomento: Universidade Comunitária da Região de Chapecó Unochapecó 